\title{
Gold Rush Families: A Review Essay
}

\section{Malcolm J. Rohrbough}

Dreams to Dust: A Diary of the California Gold Rush, 1849-1850, by Charles Ross Parke, edited by James E. Davis. Lincoln: University of Nebraska Press, 1989. xxxi, 280 pp. Illustrations, maps, notes, bibliography, index. $\$ 33.95$ cloth.

The Gold Rush Widows of Little Falls: A Story Drawn from the Letters of Pamelia and James Fergus, by Linda Peavy and Ursula Smith. St. Paul: Minnesota Historical Society Press, 1990. xxiii, 304 pp. Illustrations, maps, notes, index. $\$ 29.95$ cloth, $\$ 14.95$ paper.

To the Land of Gold and Wickedness: The 1848-1859 Diary of Lorena $L$. Hays, edited by Jeanne Hamilton Watson. St. Louis: Patrice Press, 1988. xv, $486 \mathrm{pp}$. Illustrations, maps, appendix, notes, bibliography, index. $\$ 27.95$ cloth.

THE PAST DECADE has produced an upsurge of new scholarship in the field of mining history. A new generation of historians has begun to update this venerable field littered with stories of successes and failures. This new group of studies has thrust beyond the human interest stories of fortunes won or lost to consider the relationship of the search for precious minerals to the context of American society. They have focused on the impact on the families who participated actively or passively and on the nature of the new permanent communities that emerged on the site of the mining enterprise, relating both topics to broader issues of gender, class, ethnic origin, and community. The studies of Ralph Mann, Paula Petrik, and David Emmons are among the best examples of the new scholarship. ${ }^{1}$

1. Ralph Mann, After the Gold Rush: Society in Grass Valley and Nevada City, THE ANNALS OF IOWA 51 (Winter 1992). CThe State Historical Society of Iowa, 1992. 
To keep company with these new monographs have come new published diaries, journals, and accounts based on rich collections of letters that illuminate the same questions. Among these recent publications are three that represent several sides of the new scholarship in mining and its impact on individuals and families across the nation.

CHARLES ROSS PARKE was a representative of the ambitious, middle-class professionals who joined the California gold rush "in search of gold and sight seeing" (2). The mixture of the two motives, the one public and the other less so, was a common feature of the surge of humanity to California in 1849 and the subsequent half-dozen years. A medical doctor from Whiteside County, Illinois, Parke went west in 1849 with eight friends, who organized themselves into the Como Pioneer Company, named for their hometown. Parke stayed in California for twelve months, returning to Illinois in September 1850. In the course of that year, Parke ran the range of experiences common to many Forty-niners: he mined a little and practiced his trade (in his case, medicine); he lived in the placers and in the towns; he made money but found no bonanza; and he observed and commented on the extraordinary range of humanity to be found in the gold fields. After his return, Parke practiced medicine in Bloomington (Illinois) until his retirement in 1902.

Parke's diary is most complete and insightful on his voyages to and from California; during his year there he averaged only two entries per month in his journal. His careful observation of people and landscape and his habit of speaking his mind give his account an uncommon value. Parke was very American in his intolerance for slackers on the trip overland and in his distaste for the Catholic civilization of central America on his return. He wrote with open contempt for Mexicans, whom he described as "only animals" (107), and Indians- "a buck Digger Indian is partly man and partly beast" (89)—and he displayed

California, 1849-1870 (Stanford, CA, 1982); Paula Petrik, No Step Backward: Women and Family on the Rocky Mountain Mining Frontier, Helena, Montana, 1865-1890 (Helena, 1986); David M. Emmons, The Butte Irish: Class and Ethnicity in an American Mining Town, 1875-1925 (Urbana and Chicago, 1990). 
the white American's contempt for African-Americans, whom he compared to monkeys (137). Like many other argonauts, he thought that the gold rush brought out the worst in human nature: crime, gambling, drinking, greed, and avarice. Parke was unusual in the attention he gave to the roles and activities of women on the trail and in the placers.

James E. Davis's introduction and editorial apparatus greatly increase our understanding of the significance of this document. Davis notes the American context at midcentury within which so many argonauts such as Parke headed to the golden shores of California in pursuit of not only riches but also adventure. He emphasizes the voluntary nature of the migration and the private nature of the enterprise, operating as it did without official government status or assistance (xxii). He also notes the changes wrought by the transcontinental voyage, as the participants became "different people" in the course of the experience (xxiii). To a journal of some 135 printed pages, Davis has added 110 pages of notes. His bibliography of parallel manuscript accounts, newspapers, government documents, county histories, and secondary works indicates the wideranging impact of the gold rush and the many places that this formative series of events occupies in public and private records of the mid-níneteenth century.

JEANNE HAMILTON WATSON'S edition of Lorena L. Hays's diary, published under the title To the Land of Gold and Wickedness, serves as a counterpoint to Parke's more traditional account. To begin with, Lorena L. Hays was a woman. She also left a detailed diary that covered eleven years of which the expedition to California was only one part, albeit a significant one. Her family went to California with her Uncle Henry, who had returned from the gold fields for a visit in late 1852 and intended to return to the Golden State in the migration of 1853. This was a characteristic of the gold rush too little noted, namely, that from the beginning of the gold rush, the return migration was almost as strong as the rush to California, and that many argonauts who came home then returned to California, sometimes with families or brides. Hays was not especially enthusiastic about making the voyage to California, but like many other women of the period, she found herself uprooted 
by the economic interests of the male members of her family. Make the trip she did in 1853, and she found the experience an exciting one, a contrast with her routines of the previous five years.

In framing this edition of the diary for publication, Jeanne Hamilton Watson has divided Lorena Hays's diary into three more or less equal sections: "The Illinois Years, 1848-1853," "The Trip to California, 1853," and "The California Years, 18531859." For each of those sections, Watson has written an extended introduction. That strategy works well. The contexts for Illinois, for the overland trip, and for California are remarkably different, and the division allows Watson to analyze each separately, while at the same time noting the common themes of Hays's character and her abiding interests in religion and moral uplift.

Beyond the excitement of the overland trip in 1853 , Lorena Hays's diary is instructive for what it says about the activities of one woman. Historians have long struggled with the question of representativeness in making generalizations about the California gold rush, involving as it did hundreds of thousands of people and a thousand diaries and letter collections (Watson read 130 "pioneer diaries, letters, and reminiscences" for the year 1853 alone [xi]). Because Lorena Hays had strong opinions about people, places, and events from central Illinois to California, this particular diary gives us much insight into the interests, needs, and attitudes of a young woman at midcentury with respect to the massive migration of men, and soon women and children, to California in response to the discovery of gold in 1848. In addition to her health (which was a constant worry), Hays considers, among other things, the opportunities for women in California ("There seems to be a good prospect for females to make good wages there" [67-68]); the necessity for women to marry and the ways in which migration to California would increase or decrease the prospect of an attractive marriage; and the deceptions practiced by men on the trip overland and in California itself ("Several gentlemen who are married have been passing themselves off as unmarried" [146]). These are all central questions that only a perceptive woman interested in controlling her own destiny could raise. 
Most of all, Lorena Hays had strong and pervasive religious principles. From the inception of the idea of migrating to California, she saw the expedition as divinely controlled. "I trust our Heavenly Father will direct our steps aright, and if it be his will that we shall go I pray that we may be prepared both spiritually and temporally," she confided in her diary (68). Once she reached California, however, she cast off her passive acceptance of the Lord's will to labor actively for the reformation of California society. The task was a daunting one. She identified the difficulties in her characterization of California as "the land of gold and wickedness." It was the latter quality that engaged her attention from the moment of her arrival. She began to contribute articles (under pseudonyms) to the San Francisco weekly The Golden Era, a journal with the self-proclaimed mission to cover, "literature, agriculture, the mining interest, local and foreign news, commerce, education, morals and amusements." Within such a seemingly cosmopolitan context, Lorena Hays concerned herself with women's mission to reform California society. Armed with their "secret power" from God, she wrote, women could begin a moral upsurge whose eventual result would be "that the gambler, duellist, sabbath-breaker and drunkard would soon cease to stalk in insolent dignity through the land" (quoted, p. 211). Hays suggested that woman's passive acceptance of the "wickedness" of California society stemmed from the luxury of her surroundings, a physical and natural condition that had blinded her to "vice and immorality" that lay on every side. Yet her suggestions for reforms fell within a very traditional range of Christian principles, led by temperance. She was ambivalent about women reformers on the lecture circuit because of their independence in traveling alone and making public speeches (215). Her account of California society forms a useful comparison to the arch and occasionally tongue-in-cheek descriptions of Dame Shirley (Louise A. K. S. Clappe), who wrote from the mines in 1851 and 1852 of her astonishment at the character of life in a California mining camp. ${ }^{2}$ Hays adopted the serious tone she felt appropriate to the task at hand.

2. Louise Clapp, The Shirley Letters (Layton, UT, 1970). 
Hays filled her life with visiting, correspondence, reading, and writing columns with a traditional reformist slant. After a short spell as a teacher in a distant camp, she married John Clement Bowmer, a partner in a merchant house in Ione City. Immediately after their wedding, Bowmer returned to Wisconsin for a visit with three children from his first marriage. His was another example of families divided by the gold rush to California. After his return, Lorena Hays Bowmer settled into a domestic routine in Ione City. In her remaining columns, she accepted the premise that readers preferred the "sunny side' of a story to dull dissertations on morality" (218). In her final diary entries in 1859, she wrote of her acceptance of her condition. She died in San Francisco in 1860.

No review can do justice to Jeanne Hamilton Watson's splendid editorial apparatus. In a project that stretched over twenty years, Watson tracked down every known reference to Hays, and herself visited Hays's residences in Illinois and California and retraced her route to California. In addition to extended and insightful introductions (totaling more than 130 pages) to each of the three sections, Watson has added an appendix on other members of the Hays family, store inventories from 1848 and 1855 that "provide information about the types of merchandise carried by general stores" (298); 120 pages of editorial notes; and a 40-page bibliography of additional 1853 overland travel accounts, other primary sources, maps, newspapers, census records, government documents, photographs and illustrations, and, finally, secondary works. Historians of the later stages of the California gold rush could usefully start or continue their investigations with reference to her listings. Her twenty years of detective work and writing have ended in a triumph and a new standard for the publication of gold rush diaries. And her attention to questions about women's participation in and commentary on the gold rush leads us to ask more questions about their numbers and presence. Certainly the diary of Lorena Hays makes us aware that women were not passive bystanders caught up in a great male migration.

THE LETTERS of Pamelia and James Fergus (which the authors supplement with a wide range of other materials) form the basis of the narrative in the new book by Linda Peavy and 
Ursula Smith published under the title The Gold Rush Widows of Little Falls. These letters complete our transition from women on the margins of the mining experience to a woman at the center. James Fergus followed the American dream of economic and social advantage through town building. He left a stable and prospering business in Moline, Illinois, and plunged into the development of a new town, Little Falls, Minnesota Territory. Caught in a down cycle of grasshopper plagues, the economic crisis of 1857 , and partners with poor judgment, Fergus saw his project of town building slump and slide toward oblivion. His solution was to leave his wife and family and strike out for the gold fields of Colorado and Montana, where he and others from Little Falls would recoup their fortunes.

Thus far, the story recounts an oft-told account of the movement of men in search of mineral wealth. What is different about this story is that it focuses on the community of women left behind rather than on the men who went in search of gold. The authors write that their account is a "chronicle of social disruption, of struggle to maintain a semblance of family life under extremely trying circumstances" (xv).

At the center of the story is Pamelia Fergus. Married to the sober Scot workaholic (to use a modern phrase) James Fergus in 1845, she spent much time alone. As the authors early note of Pamelia Fergus, "Though she lacked the company of her husband, Pamelia soon had that of his children" (8). With three children to keep her company, she followed her husband to Minnesota and shared his dream of a town growing and prospering. When the dream failed, she saw him off on the stagecoach as he planned to recapture their fortunes in the gold fields of the Rockies.

Pamelia Fergus and her women colleagues then prepared to soldier on in the face of the most difficult kind of natural conditions and economic privation. The Minnesota winters dominated life for half the year; for the remainder, she struggled with overwhelming tasks that included James's work as well as her own. She had to manage the family farm, with its endless decisions about planting, cultivating, harvesting, and marketing the crops, while the livestock operations required her to supervise the care of chickens, the sale of eggs, the milking of cows, and the production of butter and cheese. On the home 
front, she was responsible for the "cooking and serving of meals; sewing of clothes, quilts, curtains, and linens; supervision of the children's education, discipline, health, and moral development; maintenance of family ties with James's relatives as well as her own; and regular correspondence with James himself" (54). Finally, she had to handle the family's interests in the Little Falls Manufacturing Company, although her husband "had neither the time nor the inclination to educate her in the proper handling of company affairs" (54). It was an enterprise plagued by debts and the annual assessment of shareholders. In these varied enterprises, she had the support of other women-in-waiting, or "gold rush widows," as they came to call themselves.

The authors are especially effective in weaving together the strands of the various absent argonauts in Colorado with their "widows" in Little Falls. The women ("widows") were stoic, supportive, innovative, almost always hopeful, and occasionally depressed. The men were sometimes indifferent, sometimes devious, and (like James Fergus) sometimes frustrated by their inability to prosper in the remote camps of the Rockies. In November 1861 James Fergus returned quietly to Little Falls to avoid alerting the family's creditors to his presence. Indifferent as his success was, he remained convinced that mining offered the way to riches. Pursuant to his convictions, he left for the Montana gold fields in the spring of 1862 . The "Indian troubles" that came to Minnesota in the fall of that year caught the "widows" in its backwash, and, as a by-product, introduced a degree of prosperity in the area for the first time since its settlement. James Fergus and other men from Little Falls found initial success in Bannack, Montana, in plying their old trades of saw milling, tavern keeping, and carpentry. When James Fergus at last found a profitable claim (later a series of profitable claims), he moved Pamelia and the children to Montana. The family lived in Virginia City and later near. Helena, but James wanted more room. In 1881, over the quiet objections of his wife, James Fergus moved his family to the remote ranching "frountier" (to use Pamelia's word) near Lewiston in the eastern part of the territory. Fergus County, laid off by the Montana legislature in 1885 , is a tribute to the indomitable courage of both wife and husband. When Pamelia died of cancer in 1887 in Helena, it 
was characteristic of their life together that James was at the ranch two hundred miles distant from her.

This brief outline only hints at the many themes and people woven together by the authors. Among the significant strands that emerge are Pamelia's skills in holding together the family and in transacting many skeins of a complex, debtburdened business; her growing resentment at their adjustments in living together again, when she was expected to resume her traditional subservient role in the family and household; her quiet but real reluctance to move to ever more distant frontiers of isolation; and the circle of other "gold rush widows," whose collective fates stand parallel to her own and add a new dimension to women's experience in America's gold rushes. In a final closing of the cycle, the authors note that in 1898 , James Fergus financed a prospecting venture to the gold fields of Alaska for his grandson, who not unlike the grandfather "was married when he left for the gold fields, and he left his wife behind with little financial support" (291n).

THESE THREE SUBSTANTIAL VOLUMES remind us of the new and exciting scholarship that has become part of the study of mining frontiers. The new themes are those associated with the interaction of families and communities. The impact of the mineral rushes, from California at midcentury to the Klondike at the close of the century, spread in ever widening circles to affect individuals, families, and communities across the nation. Because the participants in the gold rushes were male, historians have focused attention on questions of governance, profit, and loss in the gold camps. The more interesting questions are connected with those left behind and with the interaction between those left behind and those who went to California. How did women and families cope with these prolonged absences? How did women managers and heads of households adjust when they were reunited with their mining spouses? What do these accounts tell us about how men regarded women and how these views changed over time? In accounts that stretch across a half-century, these three books help us to add another dimension to our understanding of the mining frontier. 
Finally, these three accounts remind us that the California gold rush had a profound impact on the Middle West. Many of the argonauts came from the farms and small towns of the Old Northwest. Over the winter they formed themselves into companies; in the spring of 1849 they headed overland to California. They left behind family members with new responsibilities and new relationships. They went to California for a range of motives that included wealth, adventure, and reform, and they made the voyage overland or by sea not just in 1849 but for a dozen years thereafter. Throughout these accounts and others, the gold rush emerges as an important chapter in the history of the Middle West, a dramatic break with the generation-long search for land and the seasonal continuity of agriculture. Hidden in the diaries and letter collections of participants-those who waited as well as those who went-lie indications of powerful changes in expectations and ambitions, individual relationships, and communities. 
Copyright of Annals of Iowa is the property of State of Iowa, by \& through the State Historical Society of Iowa and its content may not be copied or emailed to multiple sites or posted to a listserv without the copyright holder's express written permission. However, users may print, download, or email articles for individual use. 